\title{
FAKTOR YANG MEMPENGARUHI KEBERHASILAN PENGOBATAN TUBERKULOSIS (TB) PARU PADA PASIEN PASCA PENGOBATAN DI PUSKESMAS DINOYO KOTA MALANG
}

\author{
Yulinda Nur Maulidya \\ Endang Sri Redjeki \\ Erianto Fanani \\ Fakultas Ilmu Keolahragaan Universitas Negeri Malang \\ email: yulinmaulidya30@gmail.com
}

\begin{abstract}
Pulmonary tuberculosis (TB) become the most important health problem in the world. However, seeing the large number of cases of illness and death form $T B$, the disease can still be cured through treatment..The indicator used as a treatment evaluation is the success rate of treatment, and there are many factors that can influence the success of TB treatment. This study aims to determine the factors that can influence the success of treatment seen from aspects of age, education, income, type of treatment, knowladge, attitude of patients and the presence or absence of drug supevisor (PMO) in patients with post-treatment pulmonary TB in Puskesmas Dinoyo. This research is a case control study with 20 people in case group and 10 people in the control group. Tha case group is a pulmonary TB patients who has been declared cured and the control group is a pulmonary TB patients who otherwise not cured (failed, dropped out, stopped treatment).Analysis using Kolmogorov Smirnov test and Fisher's Exact test indicates that patients attitude and presencelabsence of drug supervisor (PMO) have a significant relationship with successful treatment of pulmonary TB. While age, education, income, type of treatment and knowledge have no significant relationship with the successful treatment of pulmonary TB. Patients with a "good" attitude have an opportunity to recover 4.3 times more than patients who have "bad" or "good enough" attitudes. Patients who have drug supervisor (PMO) also tend to have an opportunity to recover 13.5 times greater than patients who do not have a drug supervisor (PMO)
\end{abstract}

Abstrak: Penyakit tuberkulosis (TB) paru menjadi masalah kesehatan yang paling utama didunia. Namun, melihat banyaknya jumlah kasus kesakitan dan kematian akibat TB, penyakit ini masih dapat disembuhkan melalui pengobatan. Indikator yang digunakan sebagai evaluasi pengobatan yaitu angka keberhasilan pengobatan, dan ada banyak sekali faktor yang dapat mempengaruhi keberhasilan pengobatan TB. Penelitian ini bertujuan untuk mengetahui faktor-faktor yang dapat mempengaruhi keberhasilan pengobatan dilihat dari aspek usia, pendidikan, penghasilan, tipe pengobatan, pengetahuan, sikap pasien serta ada/tidaknya Pengawas Minum Obat (PMO) pada pasien TB paru pasca pengobatan di Puskesmas Dinoyo. Penelitian ini berupa penelitian case control dengan 20 orang pada kelompok kasus dan 10 orang pada kelompok kontrol. Kelompok kasus merupakan pasien TB paru yang telah dinyatakan sembuh dan kelompok kontrol merupakan pasien TB paru yang dinyatakan tidak sembuh (gagal, drop out, putus berobat). Hasil analisis menggunakan uji kolmogorov smirnov dan uji fisher's exact menunjukkan bahwa sikap pasien dan ada/tidaknya PMO memiliki hubungan yang signifikan dengan keberhasilan pengobatan TB paru. Sedangkan usia, pendidikan, penghasilan, tipe pengobatan dan pengetahuan tidak memiliki hubungan yang signifikan dengan keberhasilan pengobatan TB paru. Pasien yang memiliki sikap yang "baik" memiliki kesempatan untuk sembuh 4,3 kali lipat daripada pasien yang memiliki sikap "tidak baik" atau "cukup baik". Pasien yang memiliki PMO juga cenderung memiliki kesempatan untuk sembuh 13,5 kali lebih besar dibandingkan pasien yang tidak memiliki PMO.

Kata Kunci: tuberkulosis (TB) paru, faktor resiko, keberhasilan pengobatan 
Penyakit TB telah menjadi masalah kesehatan yang paling utama di dunia. Berdasarkan laporan World Health Organization (WHO) dalam Global Tuberculosis Report 2015, death rate atau angka kematian yang disebabkan oleh penyakit TB didunia memang telah menurun hingga sebesar $47 \%$ sejak tahun 1990 hingga tahun 2000. Namun, pada tahun 2014 angka kejadian dan angka kematian yang disebabkan oleh TB masih sangat tinggi dan bahkan menjadi salah satu dari lima penyakit yang mematikan pada wanita usia 20-59 tahun. Diperkirakan, jumlah penderita kasus TB sebesar 9,6 juta kasus, dimana 1,5 diantaranya meninggal akibat penyakit TB (WHO, 2015).

Berdasarkan laporan World

Health Organization (WHO) dalam

Global Tuberculosis Report 2015, Indonesia merupakan salah satu dari 3 negara yang memiliki Burden of Disease jumlah kasus TB tertinggi di dunia setelah China dan India. Diperkirakan pada tahun 2014, jumlah kematian akibat TB sebesar 100 ribu kasus atau sekitar 41 kasus per 100.000 penduduk (bagi penderita TB tanpa HIV) dan 22 ribu kasus atau sekitar 8,5 per 100.000 penduduk (bagi penderita TB disertai HIV) (WHO, 2015).

Berdasarkan survey yang dilakukan oleh Kementrian Kesehatan RI tentang cakupan penemuan kasus penyakit TB Paru, diperoleh hasil bahwa cakupan penemuan semua kasus TB di Indonesia pada tahun 2014 adalah sebesar 285.254 kasus. Sedangkan jumlah kasus baru TB Paru BTA Positif adalah sebesar 176.677 kasus. Prosentase CDR atau Case Detection Rate kasus TB di Indonesia ini adalah sebesar 70,08\% (Kemenkes RI, 2015).

Salah satu upaya untuk mengendalikan dan menanggulangi banyaknya penderita TB yaitu dengan pengobatan. Indikator yang digunakan sebagai evaluasi pengobatan yaitu angka keberhasilan program (success rate). Angka keberhasilan pengobatan ini dibentuk dari angka kesembuhan (cure rate) dan angka pengobatan lengkap.
Berdasarkan data angka kesembuhan dan keberhasilan pengobatan TB BTA Positif di Indonesia tahun 2008-2014, dapat disimpulkan bahwa terdapat penurunan angka keberhasilan pengobatan pada tahun 2014 dibandingkan 6 tahun sebelumnya. Pada tahun 2014 angka keberhasilan pengobatan sebesar $81,3 \%$. WHO menetapkan standar angka keberhasilan pengobatan sebesar $85 \%$. Dengan demikian pada tahun 2014, Indonesia belum mencapai standar tersebut dan harus memenuhi $3,7 \%$ target yang kurang. Sementara Kementerian Kesehatan menetapkan target Renstra minimal 88\% untuk angka keberhasilan pengobatan pada tahun 2014. Berdasarkan hal tersebut, capaian angka keberhasilan pengobatan tahun 2013 yang sebesar $81,3 \%$ juga tidak memenuhi target Renstra tahun 2014 (Kemenkes RI, 2015).

Ada banyak faktor yang dapat mempengaruhi keberhasilan pengobatan TB. Tinggi rendahnya TSR atau Treatment Success Rate dipengaruhi oleh beberapa faktor, antara lain; 1) Faktor pasien: pasien tidak patuh minum obat anti TB (OAT), pasien pindah fasilitas pelayanan kesehatan, dan TB nya termasuk yang resisten terhadap OAT. 2) Faktor pengawas minum obat (PMO): PMO tidak ada, PMO ada tapi kurang memantau. 3) Faktor obat: suplai OAT terganggu sehingga pasien menunda atau tidak meneruskan minum obat, dan kualitas OAT menurun karena penyimpanan tidak sesuai standar (Kemenkes RI, 2014).

Di Kota Malang, jumlah penderita TB meningkat dari tahun 2015 hingga tahun 2016. Hingga akhir tahun 2015, jumlah penderita TB yang tercatat mencapai 1.368 penderita sedangkan pada triwulan ketiga tahun 2016 meningkat menjadi 1.382 penderita (Dinkes Kota Malang, 2016). 
Berdasarkan survey awal yang dilakukan oleh peneliti, Puskesmas Dinoyo merupakan salah satu puskesmas dengan jumlah penderita TB tertinggi di Kota Malang. Berdasarkan data yang diperoleh, diketahui bahwa pada tahun 2015, jumlah penderita TB sebanyak 81 pasien dengan 58 diantaranya merupakan pasien TB Paru. Sedangkan pada tahun 2016 jumlah penderita TB adalah 80 orang dengan 66 diantaranya merupakan pasien TB Paru. Angka kesembuhan di Puskesmas Dinoyo ini terhitung sekitar $72 \%$ dari total seluruh pasien di tahun 2016.

Berdasarkan data tersebut, peneliti ingin melihat gambaran terkait

\section{METODE}

Desain penelitian yang digunakan adalah analitik observasional dengan pendekatan penelitian case control. Populasi dalam penelitian ini terdiri dari populasi kasus dan populasi kontrol. Populasi kasus merupakan pasien TB paru yang telah dinyatakan sembuh pada tahun 2016 di Puskesmas Dinoyo, yaitu sebanyak 34 orang. Sedangkan populasi kontrol merupakan pasien TB paru yang dinyatakan tidak sembuh (gagal, drop out, putus berobat) selama tahun 2016 di Puskesmas Dinoyo, yaitu sebanyak 10 orang. Teknik sampling yang digunakan adalah total sampling, sehingga seluruh populasi dijadikan sebagai sampel dalam

\section{HASIL}

\section{Karakteristik Responden}

Responden dalam penelitian ini berjumlah 44 pasien. Jumlah responden kasus adalah sebanyak 34 pasien, dan jumlah responden kontrol adalah sebanyak 10 pasien. Namun, karena satu dan lain hal (tidak bersedia menjadi responden, pindah tempat tinggal, dan faktor-faktor apasajakah yang dapat mempengaruhi keberhasilan pengobatan TB di Puskesmas Dinoyo. Dengan harapan, peneliti dapat memberikan pengetahuan dan manfaat pada berbagai pihak termasuk pihak pemberi layanan kesehatan dan penderitanya. Maka dari itu, peneliti ingin melakukan penelitian analitik observasional yang berjudul Faktor-Faktor yang Mempengaruhi Keberhasilan Pengobatan Tuberkulosis (TB) Paru pada Pasien Pasca Pengobatan di Puskesmas Dinoyo Kota Malang.

penelitian ini. Instrumen penelitian yang digunakan adalah kuisioner penelitian yang telah diuji reliabilitas dan validitasnya, serta rekam medis pasien TB Puskesmas Dinoyo. Penelitian ini dilaksanakan di wilayah kerja Puskesmas Dinoyo selama 2 bulan, yaitu bulan Februari-Maret 2017. Pengumpulan data dilakukan dengan membagikan instrumen penelitian yang berupa kuisioner pada masing-masing responden. Analisis data yang digunakan adalah analisis univariat dan analisis bivariat menggunakan uji kolmogorovsmirnov dan uji fisher's exact dengan aplikasi SPSS vw 16.

alamat tidak jelas) maka jumlah akhir yang berhasil menjadi responden dalam penelitian ini adalah; responden kasus sebanyak 20 orang dan responden kontrol sebanyak 10 orang. Berikut adalah karakteristik responden dalam penelitian ini: 
Tabel 1. Karakteristik Responden Berdasarkan Jenis Kelamin

\begin{tabular}{lcccccc}
\hline \multirow{2}{*}{ Jenis Kelamin } & \multicolumn{3}{c}{ Total } \\
\cline { 2 - 7 } & \multicolumn{2}{c}{ Sembuh } & \multicolumn{2}{c}{ Tidak Sembuh } & \multicolumn{2}{c}{ Total } \\
\cline { 2 - 7 } & $\mathrm{N}$ & $\%$ & $\mathrm{~N}$ & $\%$ & $\mathrm{~N}$ & $\%$ \\
\hline Laki-laki & 9 & $45 \%$ & 6 & $60 \%$ & 15 & $50 \%$ \\
Perempuan & 11 & $55 \%$ & 4 & $40 \%$ & 15 & $50 \%$ \\
\hline Total & $\mathbf{2 0}$ & $\mathbf{1 0 0 \%}$ & $\mathbf{1 0}$ & $100 \%$ & 30 & $100 \%$ \\
\hline
\end{tabular}

Berdasarkan hasil penelitian diperoleh data responden berdasarkan jenis kelamin, pada kelompok kasus (pasien sembuh) yang berjenis kelamin perempuan yaitu sebanyak 11 orang atau
55\% sedangkan pada kelompok kontrol (pasien tidak sembuh) lebih banyak ada pada pasien berjenis kelamin laki-laki yaitu sebanyak 6 orang atau $60 \%$.

Usia

Tabel 2. Tabulasi Silang Usia dengan Keberhasilan Pengobatan TB Paru

\begin{tabular}{|c|c|c|c|c|c|c|c|}
\hline \multirow{3}{*}{ Usia } & \multicolumn{6}{|c|}{ Keberhasilan Pengobatan TB Paru } & \multirow{3}{*}{$P$ value } \\
\hline & \multicolumn{2}{|c|}{ Sembuh } & \multicolumn{2}{|c|}{ Tidak Sembuh } & \multicolumn{2}{|c|}{ Total } & \\
\hline & $\mathrm{N}$ & $\%$ & $\mathrm{~N}$ & $\%$ & $\mathrm{~N}$ & $\%$ & \\
\hline 15-19 tahun & 1 & $5 \%$ & 1 & $0 \%$ & 2 & $7 \%$ & \multirow{12}{*}{0,775} \\
\hline 20-24 tahun & 6 & $30 \%$ & 4 & $60 \%$ & 10 & $33 \%$ & \\
\hline 25-29 tahun & 2 & $10 \%$ & 2 & $20 \%$ & 4 & $13 \%$ & \\
\hline 30-34 tahun & 2 & $10 \%$ & 1 & $0 \%$ & 3 & $10 \%$ & \\
\hline 35-39 tahun & 1 & $5 \%$ & 1 & $0 \%$ & 2 & $7 \%$ & \\
\hline 40-44 tahun & 1 & $5 \%$ & 0 & $0 \%$ & 1 & $3 \%$ & \\
\hline 45-49 tahun & 2 & $10 \%$ & 0 & $0 \%$ & 2 & $7 \%$ & \\
\hline 50-54 tahun & 0 & $0 \%$ & 1 & $20 \%$ & 1 & $3 \%$ & \\
\hline 55-59 tahun & 2 & $10 \%$ & 0 & $0 \%$ & 2 & $7 \%$ & \\
\hline 60-64 tahun & 1 & $5 \%$ & 0 & $0 \%$ & 1 & $3 \%$ & \\
\hline$>64$ tahun & 2 & $10 \%$ & 0 & $0 \%$ & 2 & $7 \%$ & \\
\hline Total & 20 & $100 \%$ & 10 & $100 \%$ & 30 & $100 \%$ & \\
\hline
\end{tabular}

Berdasarkan tabel diatas, dapat terlihat bahwa baik pada kelompok kasus (pasien sembuh) maupun kelompok kontrol (pasien tidak sembuh) mayoritas responden berada pada kategori usia 20-24 tahun. Yaitu sebanyak 6 (30\%) orang pada kelompok kasus, dan pada kelompok kontrol sebanyak 4 orang $(60 \%)$. Berdasarkan hasil analisis menggunakan uji kolmogorov-smirnov diperoleh nilai $p$ value $(0,775)>\alpha(0,05)$ sehingga dapat diinterpretasikan bahwa tidak ada hubungan antara usia dengan keberhasilan pengobatan TB paru di Puskesmas Dinoyo. 


\section{Pendidikan}

Tabel 3. Tabulasi Silang Pendidikan dengan Keberhasilan Pengobatan TB Paru

\begin{tabular}{|c|c|c|c|c|c|c|c|}
\hline \multirow{3}{*}{ Pendidikan } & \multicolumn{6}{|c|}{ Keberhasilan Pengobatan TB Paru } & \multirow{3}{*}{$P$ value } \\
\hline & \multicolumn{2}{|c|}{ Sembuh } & \multicolumn{2}{|c|}{ Tidak Sembuh } & \multicolumn{2}{|c|}{ Total } & \\
\hline & $\mathrm{N}$ & $\%$ & $\mathrm{~N}$ & $\%$ & $\mathrm{~N}$ & $\%$ & \\
\hline \multicolumn{8}{|l|}{ Tidak Menempuh Jenjang } \\
\hline SD/MI/Paket A & 6 & $30 \%$ & 1 & $10 \%$ & 7 & $23 \%$ & \multirow{5}{*}{0,645} \\
\hline SMP/MTs/Paket B & 2 & $10 \%$ & 2 & $20 \%$ & 4 & $13 \%$ & \\
\hline SMA/MA/SMK/Paket C & 7 & $35 \%$ & 6 & $60 \%$ & 13 & $43 \%$ & \\
\hline Diploma/Perguruan Tinggi & 4 & $20 \%$ & 1 & $10 \%$ & 5 & $17 \%$ & \\
\hline Total & 20 & $100 \%$ & 10 & $100 \%$ & 30 & $100 \%$ & \\
\hline \multicolumn{3}{|c|}{$\begin{array}{l}\text { Berdasarkan hasil tabulasi } \\
\text { diketahui bahwa baik pada kelompok } \\
\text { kasus (pasien sembuh) maupun pada } \\
\text { kelompok kontrol (pasien tidak sembuh) } \\
\text { sebagian besar responden }(43 \%) \\
\text { memiliki pendidikan formal terakhir } \\
\text { hingga SMA/MA/SMK/ Paket C. Dari } \\
\text { ke } 13 \text { responden (43\%) yang } \\
\text { berpendidikan SMA/MA/SMK/ Paket C, }\end{array}$} & \multicolumn{5}{|c|}{$\begin{array}{l}\text { sebanyak } 7 \text { orang }(35 \%) \text { dan pada } \\
\text { kelompok kontrol (tidak sembuh) } \\
\text { sebanyak } 6 \text { orang }(60 \%) \text {. Hasil analisis } \\
\text { menggunakan uji kolmogorov-smirnov } \\
\text { diperoleh nilai } p \text { value }(0,645)>\alpha(0,05) \\
\text { sehingga dapat diinterpretasikan bahwa } \\
\text { tidak ada hubungan antara pendidikan } \\
\text { dengan keberhasilan pengobatan TB } \\
\text { paru di Puskesmas Dinoyo. }\end{array}$} \\
\hline
\end{tabular}

\section{Penghasilan}

Tabel 4. Tabulasi Silang Tingkat Penghasilan dengan Keberhasilan Pengobatan TB Paru

\begin{tabular}{|c|c|c|c|c|c|c|c|}
\hline \multirow{3}{*}{ Tingkat Penghasilan } & \multicolumn{4}{|c|}{ Total } & & & \multirow{3}{*}{$P$ value } \\
\hline & \multicolumn{2}{|c|}{ Sembuh } & \multicolumn{2}{|c|}{ Tidak Sembuh } & \multicolumn{2}{|c|}{ Total } & \\
\hline & $\mathrm{N}$ & $\%$ & $\mathrm{~N}$ & $\%$ & $\mathrm{~N}$ & $\%$ & \\
\hline < Rp. 1.500 .000 & 15 & $75 \%$ & 8 & $80 \%$ & 23 & $77 \%$ & \multirow{5}{*}{0,387} \\
\hline Rp. $1.500 .000 \mathrm{sd}$ Rp. 2.500 .000 & 0 & $0 \%$ & 1 & $10 \%$ & 1 & $3 \%$ & \\
\hline Rp. 2.500.000 sd Rp. 3.500 .000 & 2 & $10 \%$ & 1 & $10 \%$ & 3 & $10 \%$ & \\
\hline$>$ Rp. 3.500 .000 & 3 & $15 \%$ & 0 & $0 \%$ & 3 & $10 \%$ & \\
\hline Total & 20 & $100 \%$ & 10 & $100 \%$ & 30 & $100 \%$ & \\
\hline
\end{tabular}

Berdasarkan hasil tabulasi diketahui bahwa baik pada kelompok kasus (pasien sembuh) maupun pada kelompok kontrol (pasien tidak sembuh) sebagian besar responden (77\%) berpenghasilan rendah $(<\mathrm{Rp}$. 1.500.000). Dari ke 23 responden (77\%) yang memiliki tigkat penghasilan rendah (< Rp. 1.500.000) pada kelompok kasus (sembuh) sebanyak 15 orang $(75 \%)$ dan pada kelompok kontrol (tidak sembuh) sebanyak 8 orang $(80 \%)$. Hasil uji mengguakan uji kolmogorov-smirnov diperoleh nilai $p$ value $(0,387)>\alpha(0,05)$ sehingga dapat diinterpretasikan bahwa tidak ada hubungan antara tingkat penghasilan dengan keberhasilan pengobatan TB paru di Puskesmas Dinoyo. 


\section{Tipe Pengobatan}

Tabel 5. Tabulasi Silang Tipe Pengobatan dengan Keberhasilan Pengobatan TB Paru

\begin{tabular}{|c|c|c|c|c|c|c|c|}
\hline \multirow{3}{*}{ Tipe Pengobatan } & \multicolumn{6}{|c|}{ Keberhasilan Pengobatan TB Paru } & \multirow{3}{*}{$P$ value } \\
\hline & \multicolumn{2}{|c|}{ Sembuh } & \multicolumn{2}{|c|}{ Tidak Sembuh } & \multicolumn{2}{|c|}{ Total } & \\
\hline & $\mathrm{N}$ & $\%$ & $\mathrm{~N}$ & $\%$ & $\mathrm{~N}$ & $\%$ & \\
\hline Kategori I & 17 & $85 \%$ & 7 & $70 \%$ & 24 & $80 \%$ & \\
\hline Kategori II & 3 & $15 \%$ & 3 & $30 \%$ & 6 & $20 \%$ & 0,306 \\
\hline Total & 20 & $100 \%$ & 10 & $100 \%$ & 30 & $100 \%$ & \\
\hline
\end{tabular}

Berdasarkan hasil tabulasi diketahui bahwa baik pada kelompok kasus (pasien sembuh) maupun kelompok kontrol (pasien tidak sembuh) sebagian besar responden (80\%) mendapatkan tipe pengobatan kategori I. Dari ke 24 responden (80\%) yang mendapatkan tipe pengobatan kategori I, yang dinyatakan sembuh sebanyak 17 orang $(85 \%)$ dan yang dikatakan tidak sembuh sebanyak 7 orang (70\%). Hasil uji menggunakan uji fisher's exact diperoleh nilai $p$ value $(0,306)>\alpha(0,05)$ sehingga dapat diinterpretasikan bahwa tidak ada hubungan antara tipe pengobatan dengan keberhasilan pengobatan TB paru di Puskesmas Dinoyo.

\section{Pengetahuan}

Tabel 6. Tabulasi Silang Pengetahuan dengan Keberhasilan Pengobatan TB Paru

\begin{tabular}{|c|c|c|c|c|c|c|c|}
\hline \multirow{3}{*}{ Pengetahuan } & \multicolumn{6}{|c|}{ Keberhasilan Pengobatan TB Paru } & \multirow{3}{*}{ P value } \\
\hline & \multicolumn{2}{|c|}{ Sembuh } & \multicolumn{2}{|c|}{ Tidak Sembuh } & \multicolumn{2}{|c|}{ Total } & \\
\hline & $\mathrm{N}$ & $\%$ & $\mathrm{~N}$ & $\%$ & $\mathrm{~N}$ & $\%$ & \\
\hline Cukup Baik & 3 & $15 \%$ & 5 & $50 \%$ & 8 & $27 \%$ & \multirow{3}{*}{0,078} \\
\hline Baik & 17 & $85 \%$ & 5 & $50 \%$ & 22 & $73 \%$ & \\
\hline Total & 20 & $100 \%$ & 5 & $100 \%$ & 30 & $100 \%$ & \\
\hline
\end{tabular}

Berdasarkan hasil tabulasi diketahui bahwa baik pada kelompok kasus (pasien sembuh) maupun pada kelompok kontrol (pasien tidak sembuh) sebagian besar responden (73\%) dinyatakan memiliki pengetahuan yang "baik". Dari 22 responden (73\%) tersebut yang berhasil dinyatakan sembuh adalah sebanyak 17 oarng
(85\%) dan yang yang dinyatakan tidak sembuh adalah sebanyak 5 orang (50\%). Hasil analisis menggunakan uji fisher's exact diperoleh nilai $p$ value $(0,078)>\alpha$ $(0,05)$ sehingga dapat diinterpretasikan bahwa tidak ada hubungan antara pengetahuan dengan keberhasilan pengobatan TB paru di Puskesmas Dinoyo. 


\section{Sikap Pasien}

Tabel 7. Tabulasi Silang Sikap Pasien dengan Keberhasilan Pengobatan TB Paru

\begin{tabular}{|c|c|c|c|c|c|c|c|c|}
\hline \multirow{3}{*}{ Sikap Pasien } & \multicolumn{6}{|c|}{ Keberhasilan Pengobatan TB Paru } & \multirow{3}{*}{ P value } & \multirow{3}{*}{ OR $(95 \%$ IK $)$} \\
\hline & \multicolumn{2}{|c|}{ Sembuh } & \multicolumn{2}{|c|}{ Tidak Sembuh } & \multicolumn{2}{|c|}{ Total } & & \\
\hline & $\mathrm{N}$ & $\%$ & $\mathrm{~N}$ & $\%$ & $\mathrm{~N}$ & $\%$ & & \\
\hline \multirow{2}{*}{$\begin{array}{l}\text { Cukup Baik } \\
\text { Baik }\end{array}$} & 0 & $0 \%$ & 4 & $40 \%$ & 4 & $13 \%$ & \multirow{3}{*}{0,008} & \multirow{3}{*}{$\begin{array}{c}4,333 \\
(2,148-8,742)\end{array}$} \\
\hline & 20 & $100 \%$ & 6 & $60 \%$ & 26 & $87 \%$ & & \\
\hline Total & 20 & $100 \%$ & 10 & $100 \%$ & 30 & $100 \%$ & & \\
\hline
\end{tabular}

Berdasarkan hasil tabulasi diketahui bahwa baik pada kelompok kasus (pasien sembuh) maupun pada kelompok kontrol (pasien tidak sembuh) mayoritas responden $(87 \%)$ dinyatakan memiliki sikap yang "baik" saat menjalani pengobatan. Dari 26 responden $(87 \%)$ tersebut, yang berhasil dinyatakan sembuh adalah sebanyak 20 responden $(100 \%)$ dan yang dinyatakan tidak sembuh adalah sebanyak 6 orang (60\%). Hasil analisis menggunakan uji fisher's exact diperoleh nilai $p$ value $(0,008)<\alpha(0,05)$ sehingga dapat diinterpretasikan bahwa ada hubungan antara sikap pasien dengan keberhasilan pengobatan TB paru di Puskesmas Dinoyo. Sedangkan besar resiko bagi pasien yang memiliki sikap yang "baik" selama menjalani pengobatan adalah 4,333 kali lebih besar untuk sembuh dibandingkan dengan pasien yang memiliki sikap "kurang baik" maupun "cukupbaik".

\section{Ada/Tidaknya PMO}

Tabel 8. Tabulasi Silang Pengawas Minum Obat (PMO) dengan Keberhasilan Pengobatan TB Paru

\begin{tabular}{|c|c|c|c|c|c|c|c|c|}
\hline \multirow{3}{*}{$\begin{array}{c}\text { Pengawas } \\
\text { Minum Obat } \\
\text { (PMO) }\end{array}$} & \multicolumn{6}{|c|}{ Keberhasilan Pengobatan TB Paru } & \multirow{3}{*}{$\begin{array}{c}P \\
\text { value }\end{array}$} & \multirow{3}{*}{$\begin{array}{c}\text { OR }(95 \% \\
\text { IK) }\end{array}$} \\
\hline & \multicolumn{2}{|c|}{ Sembuh } & \multicolumn{2}{|c|}{ Tidak Sembuh } & \multicolumn{2}{|c|}{ Total } & & \\
\hline & $\mathrm{N}$ & $\%$ & $\mathrm{~N}$ & $\%$ & $\mathrm{~N}$ & $\%$ & & \\
\hline Ada & 18 & $90 \%$ & 4 & $40 \%$ & 22 & $73 \%$ & \multirow{3}{*}{0,026} & \multirow{3}{*}{$\begin{array}{c}13,5 \\
(1,955- \\
93,246)\end{array}$} \\
\hline Tidak Ada & 2 & $10 \%$ & 6 & $60 \%$ & 8 & $27 \%$ & & \\
\hline Total & 20 & $100 \%$ & 10 & $100 \%$ & 30 & $100 \%$ & & \\
\hline
\end{tabular}

Berdasarkan hasil tabulasi diketahui bahwa pada kelompok kasus (pasien sembuh) sebagian besar responden yaitu sebanyak 22 orang (73\%) menyatakan memiliki PMO, sedangkan pada kelompok kontrol (pasien tidak sembuh) sebagian besar menyatakan tidak memiliki PMO yaitu sebanyak 6 orang (60\%). Dari 22 orang (73\%) yang menyatakan memiliki PMO, 18 orang diantaranya berhasil dinyatakan sembuh, sedangkan 4 sisanya dinyatakan tidak sembuh. Hasil analisis menggunakan uji fisher's exact diperoleh nilai $p$ value $(0,026)<\alpha(0,05)$ sehingga dapat diinterpretasikan bahwa ada hubungan antara ada/tidaknya Pengawas Minum Obat (PMO) dengan keberhasilan pengobatan TB paru di Puskesmas Dinoyo. Sedangkan besar resiko bagi pasien yang memiliki PMO adalah 13,5 kali lebih besar untuk sembuh dibandingkan pasien yang tidak memiliki

PMO. 


\section{PEMBAHASAN}

\section{Hubungan Usia dengan Keberhasilan Pengobatan TB Paru}

Hasil penelitian menunjukkan bahwa tidak ada hubungan antara usia dengan keberhasilan pengobatan TB paru di Puskesmas Dinoyo. Hasil ini didasarkan pada uji kolmogorovsmirnov yang diperoleh $p$ value $(0,775)$ (yang lebih besar dari $\alpha$ $0,05)$.

Hasil penelitian ini sesuai dengan penelitian yang dilakukan oleh Diana (2014) yang menyatakan bahwa tidak ada hubungan antara umur dengan kepatuhan berobat pasien TB. Hasil penelitian menunjukkan bahwa $p$ value $(0,948)$ $>\alpha(0,05)$ (Diana, 2014: 247).

Kemenkes RI menyatakan bahwa sekitar 15,49\% pasien TB paru adalah kelompok usia yang termasuk usia produktif secara ekonomis, yaitu 15-24 tahun (Kemenkes RI, 2014). Usia produktif merupakan masa yang berperan penting dimana mereka cenderung sering keluar rumah dan memudahkan proses penularan TB paru (Tirtana, 2011). Namun jika dibandingkan dengan hasil dari penelitian diatas, usia bukanlah satusatunya alasan atau faktor seseorang terkena penyakit tuberkulosis, juga bukan merupakan satu-satunya faktor yang berpengaruh pada keberhasilan pengobatan. Sehingga dapat disimpulkan bahwa berapapun usia pasien, tetap mempunyai kesempatan untuk sembuh jika didukung oleh kepatuhan minum obat dan menjalani pengobatan.

\section{Hubungan Pendidikan dengan Keberhasilan Pengobatan TB Paru}

Hasil penelitian menunjukkan bahwa tidak ada hubungan antara pendidikan dengan keberhasilan pengobatan TB paru di Puskesmas Dinoyo. Hasil ini didasarkan pada uji kolmogorov-smirnov yang diperoleh $p$ value (0.645) (dimana lebih besar dari $\alpha 0,05)$.

Hasil penelitian ini sesuai dengan penelitian yang dilakukan oleh Kholifah (2009) yang menyatakan bahwa tidak ada hubungan antara tingkat pendidikan dengan kesembuhan penderita TB paru (Kholifah, 2009:66). Penelitian lain yang dilakukan oleh Harnanik (2014) juga menyatakan bahwa tidak ada hubungan antara pendidikan dengan keberhasilan pengobatan TB paru, didasarkan pada hasil analisis $p$ value $(0,056)$ (lebih besar dari $\alpha$ 0,05) (Harnanik, 2014).

Berdasarkan hasil penelitian yang didapatkan oleh peneliti, mayoritas responden menganggap bahwa penyakit TB paru merupakan penyakit yang berbahaya dan menakutkan, sehingga baik responden yang bersekolah hingga SD maupun yang berpendidikan hingga lulus SMA atau perguruan tinggi, mereka merasa terdorong untuk memeriksakan diri ke fasilitas pelayanan kesehatan dan menjalani pengobatan selama 6-8 bulan. oleh sebab itu, pada dasarnya tingkat pendidikan seseorang tidak berpengaruh secara langsung terhadap keberhasilan pengobatan TB paru. 


\section{Hubungan Tingkat Penghasilan dengan Keberhasilan Pengobatan TB Paru}

Hasil penelitian menunjukkan bahwa tidak ada hubungan antara tingkat penghasilan dengan keberhasilan pengobatan TB paru di Puskesmas Dinoyo. Hasil ini didasarkan pada uji kolmogorov smirnov yang diperoleh $p$ value $(0,387)$ (dimana lebih besar dari $\alpha$ $0,05)$.

Hasil penelitian ini sesuai dengan penelitian yang dilakukan oleh Nurna (2015) yang menyatakan bahwa tidak ada hubungan antara tingkat pendapatan penderita TB paru dengan kepatuhan memeriksakan dahak selama menjalani pengobatan yang didasarkan pada analisis $p$ value $(0,48)>\alpha(0,05)$ (Nurna, 2015:127). Penelitian yang dilakukan oleh Dhina Nurlita (2015) juga menyatakan hasil yang sama, yaitu tidak ada hubungan antara penghasilan dengan kesembuhan penderita TB paru. Didukung dengan nilai $p$ value $(0,059)$ (dimana lebih besar dari $\alpha$ 0,05). Dalam penelitian ini disebutkan bahwa pada dasarnya pengobatan tuberkulosis merupakan program penanggulangan penyakit secara nasional sehingga biaya yang dikeluarkan tidak besar, dan akses menuju pelayanan kesehatan juga tidak menjadi masalah, sehingga baik pasien dengan tingkat penghasilan yang rendah maupun pasien dengan tingkat penghasilan yang tinggi sama sama memiliki kesempatan untuk dapat mengakses pengobatan dengan baik (Nurlita, 2015:146).

\section{Hubungan Tipe Pengobatan dengan Keberhasilan Pengobatan TB Paru}

Hasil penelitian menunjukkan bahwa tidak ada hubungan antara tipe pengobatan dengan keberhasilan pengobatan TB paru di Puskesmas Dinoyo. Hasil ini didasarkan pada uji fisher's exact yang diperoleh nilai $p$ value $(0,306)$ (dimana lebih besar dari $\alpha 0,05)$.

Hasil penelitian ini sesuai dengan penelitian yang dilakukan oleh Kholifah (2009), yang menyatakan bahwa tidak ada hubungan antara riwayat pengobatan (tipe pengobatan) dengan kesembuhan penderita TB paru (Kholifah, 2009:70). Klasifikasi tipe pengobatan ditentukan untuk panduan OAT atau panduan minum obat. Berdasarkan panduan kategori OAT, kategori I memerlukan waktu 6 bulan pengobatan dan kategori II memerlukan waktu 8 bulan pengobatan dengan dosis obat yang berbeda-beda (Kemenkes RI, 2014: 24-25) untuk menjamin kesembuhan selama periode pengobatan, obat harus diminum dan penderita diawasi secara ketat oleh Pengawas Minum Obat (PMO) baik dari teman maupun keluarga agar terjamin kepatuhan penderita dalam minum obat (Fachmi, 2004 dalam Kholifah, 2009: 80-81).

Pada dasarnya setiap penderita TB memiliki kesempatan yang sama untuk sembuh setelah menjalani pengobatan baik pada pasien kategori I maupun pasien kategori II, selama pasien selalu patuh dalam mengonsumsi OAT dan dalam menjalani pengobatan. Sehingga dari beberapa hasil penelitian diatas dapat disimpulkan bahwa tidak ada hubungan antara tipe pengobatan 
dengan keberhasilan pengobatan TB paru.

\section{Hubungan Pengetahuan dengan Keberhasilan Pengobatan TB Paru}

Hasil penelitian menunjukkan bahwa tidak ada hubungan antara pengetahuan dengan keberhasilan pengobatan TB paru di Puskesmas Dinoyo. Hasil ini didasarkan pada uji fisher's exact yang diperoleh nilai $p$ value $(0,078)$ (dimana lebih besar dari $\alpha 0,05)$.

Hasil penelitian ini sesuai dengan penelitian yang dilakukan oleh Diana (2014) yang menyatakan bahwa tidak ada hubungan antara pengetahuan dengan kepatuhan berobat pasien TB. Hasil analisis menyatakan nilai $p$ value $(0,619)>\alpha$ $(0,05)$ (Diana, 2014:247). Didukung dengan penelitian terdahulu yang dilakukan oleh Nurmala (2002) yang menyatakan bahwa pengetahuan responden tidak berpengaruh terhadap keberhasilan program penanggulangan TB paru, dimana nilai $p$ value $(0,284)$ juga lebih dari $\alpha$ $(0,05)$. Disebukan didalamnya bahwa hal yang diduga menjadi penyebab tidak adanya pengaruh antara pengetahuan terhadap kesembuhan pasien adalah karena pengetahuan pasien tidak ditindak lanjuti dengan sikap. Hal ini berarti semakin tinggi atau rendahnya pengetahuan penderita, tidak mempengaruhi kesembuhannya (Nurmala, 2002:4647).

\section{Hubungan Sikap Pasien dengan Keberhasilan Pengobatan TB Paru}

Hasil penelitian menunjukkan bahwa ada hubungan antara sikap pasien dengan keberhasilan pengobatan TB paru di Puskesmas Dinoyo. Hal ini didasarkan pada uji fisher's exact yang diperoleh nilai $p$ value $(0,008)$ (dimana kurang dari $\alpha$ $0,05)$, dan meningkatkan resiko sebesar 4,33 kali lipat untuk sembuh apabila memiliki sikap yang "baik" selama menjalani pengobatan (IK $95 \%$ OR $=2,148-8,742$ ).

Hasil penelitian ini didukung oleh penelitian terkait yang dilakukan oleh Kholifah (2009) yang menyatakan bahwa penderita TB paru yang mempunyai sikap cukup dan baik (97,4\% responden) berhasil menjalani pengobatan hingga dinyatakan sembuh. Sedangkan responden yang mempunyai sikap kurang baik selama menjalani pengobatan memiliki resiko 11,483 kali untuk tidak sembuh dibandingkan responden yang mempunyai sikap cukup dan baik selama menjalani pengobatan (Kholifah, 2009: 75-76). Berdasarkan teori yang dikemukakan oleh M. Hariwijaya, dkk (2007) dalam Kholifah (2009), penyakit tuberkulosis pada dasarnya dapat disembuhkan secara tuntas apabila pasien/penderita selalu mengikuti anjuran dan arahan dari tenaga kesehatan untuk minum obat secara teratur dan rutin sesuai dengan dosis yang dianjurkan, serta mengonsumsi makanan yang bergizi cukup untuk meningkatkan daya tahan tubuh pasien (Kholifah, 2009: 66-67).

Hasil penelitian lain yang mendukung adalah penelitian yang dilakukan oleh Okanurak (2008) yang mengaitkan antara tingkat pengetahuan dan sikap pasien terhadap keberhasilan pengobatan tuberkulosis. Okanurak (2008) menyatakan bahwa tingkat pengetahuan pasien terkait penyakit TB berkonstribusi pada keberhasilan pengobatan. Pengetahuan yang baik dibutuhkan untuk merubah sikap 
seseorang terhadap sesuatu. Sikap ini dapat mempengaruhi intensi seseorang untuk berperilaku lebih baik. Sehingga secara tidak langsung sikap pasien dalam hal ini juga mempengaruhi keberhasilan pengobatan TB paru (Okanurak, 2008:1163).

\section{Hubungan Ada/Tidaknya PMO dengan Keberhasilan Pengobatan TB Paru}

Hasil penelitian menunjukkan bahwa ada hubungan antara ada/tidaknya PMO dengan keberhasilan pengobatan TB paru di Puskesmas Dinoyo. Hal ini didasarkan pada uji fisher's exact yang diperoleh nilai $p$ value $(0,026)$ (dimana kurang dari $\alpha 0,05$ ). Besar resiko bagi pasien yang memiliki PMO adalah 13,5 kali lebih besar untuk sembuh dibandingkan pasien yang tidak memiliki PMO (IK 95\% $\mathrm{OR}=1,955-93,246$ ).

Hal ini sesuai dengan teori yang dikemukakan oleh $\mathrm{M}$. Hariwijaya dan Sutano (2007) dalam Kholifah (2009) bahwa untuk menjamin keteraturan dalam meminum obat dan dalam menjalani pengobatan diperlukan seorang PMO (Kholifah, 2009:83). Penelitian yang dilakukan oleh Ma'arif (2012) juga menyatakan bahwa kecenderungan semakin baik peran PMO maka keberhasilan pengobatan semakin meningkat dan sebaliknya apabila semakin buruk peran PMO maka keberhasilan pengobatan semakin kecil. Berdasarkan analisis yang dilakukan dapat disimpulkan bahwa terdapat pengaruh peranan PMO terhadap keberhasilan pengobatan penderita TB paru (Ma'arif, 2012:11).

Sedangkan penelitian yang dilakukan oleh Pandapotan P.
Sormin, dkk (2014) mengaitkan antara peranan PMO terhadap kepatuhan minum obat. Hasil analisis menunjukkan bahwa peran PMO yang baik dapat berpengaruh pada kepatuhan berobat penderita TB paru (Sormin, 2014). Didukung oleh penelitian yang dilakukan oleh Muniroh. N, dkk (2012) yang menyatakan bahwa ada hubungan antara kepatuhan minum obat dengan kesembuhan TB paru. Dalam penelitian ini disebutkan bahwa semua penderita secara teoritis dapat sembuh dari TB paru, asalkan rajin dan patuh dalam mengonsumsi obat sampai fase pengobatan selesai dijalankan (Muniroh, 2012:38).

Secara keseluruhan dapat disimpulkan bahwa pasien yang memiliki PMO cenderung lebih teratur dalam minum obat dan patuh dalam menjalani pengobatan. Dalam hal ini peran PMO yang dapat menjalankan tugasnya dengan baik sangat berpengaruh dalam keberhasilan pengobatan TB paru.

\section{KESIMPULAN}

1. Kejadian kasus TB paru yang diteliti sebanyak 30 responden dengan distribusi karakteristik rata-rata pada kelompok usia 2024 tahun sebanyak 10 orang (33\%), tingkat pendidikan formal terakhir mayoritas pada jenjang SMA/MA/SMK/Paket C sebanyak 13 orang (43\%), mayoritas responden memiliki tingkat penghasilan rendah (<Rp. 1.500.000) sebanyak 23 orang (77\%), mayoritas responden memiliki tipe pengobatan kategori I sebanyak 24 orang (80\%), rata-rata responden 
memiliki pengetahuan yang "baik" sebanyak 22 orang (73\%), dan sikap yang "baik" pula sebanyak 26 orang (87\%), sementara proporsi responden yang memiliki PMO (Pengawas Minum Obat) adalah sebanyak 22 orang $(73 \%)$.

2. Hasil penelitian menunjukkan bahwa faktor-faktor yang paling mempengaruhi keberhasilan pengobatan tuberkulosis (TB) paru pada pasien pasca pengobatan di Puskesmas Dinoyo secara berturut-turut berdasarkan besar nilai OR (Odd Ratio) adalah; 1) Ada/Tidaknya PMO $(\mathrm{OR}=13,5), 2)$ Sikap Pasien $(\mathrm{OR}=4,3), 3)$ Tipe Pengobatan $(\mathrm{OR}=2,43), 4)$ Pengetahuan $(\mathrm{OR}=0,17), 5)$ Penghasilan, 6) Pendidikan, dan 7) Usia.

3. Hasil analisis jika dibandingkan dengan kelompok kontrol (pasien tidak sembuh) menunjukkan bahwa sikap pasien dan ada/tidaknya Pengawas Minum Obat (PMO) memiliki hubungan yang cukup signifikan dengan keberhasilan pengobatan TB paru pada pasien pasca pengobatan di Puskesmas Dinoyo. Faktor usia, pendidikan, penghasilan, tipe pengobatan dan pengetahuan tidak memiliki hubungan yang signifikan dengan keberhasilan pengobatan TB paru pada pasien pasca pengobatan di Puskesmas Dinoyo.

\section{SARAN}

1. Bagi peneliti selanjutnya, penelitian ini bisa menjadi penelitian pendahuluan untuk menganalisis faktor-faktor lain yang mempengaruhi

keberhasilan pengobatan TB paru. Selain itu, penelitian ini dilakukan dengan jumlah sampel yang relatif sedikit sehingga penambahan sampel sangat disarankan.

2. Bagi pihak Puskesmas Dinoyo, hasil dari penelitian ini bisa menjadi evaluasi selama menjalani pengobatan TB paru, baik bagi petugas kesehatan maupun bagi pasien sendiri. Hasil penelitian ini juga bisa diinformasikan kepada pasien TB paru terkait, sehingga pasien bisa lebih sadar akan pentingnya menjaga kepatuhan dalam mengonsumsi OAT dan dalam menjalani pengobatan.

3. Bagi Jurusan Ilmu Kesehatan Masyarakat, penelitian ini masih merupakan penelitian awal dari penelitian-penelitian lainnya. Sehingga diharapkan penelitian ini bisa dijadikan sebagai referensi bagi peneliti lain dan bagi perbendaharaan ilmu kesehatan masyarakat sendiri. Agar penelitian yang telah dilakukan ini bisa lebih bermanfaat bagi orang lain.

\section{DAFTAR RUJUKAN}

Diana, Ida. 2014. Hubungan Pengetahuan dan Sikap dengan Kepatuhan Berobat pada Pasien TB Paru yang Rawat Jalan di Jakarta Tahun 2014. Media Litbangkes, 26 (4): 243248.

Dinas Kesehatan Kota Malang. 2016. Laporan Triwulan Penemuan Pasien TB. Malang: Dinas Kesehatan Kota Malang. Haniyah, S, dkk. 2012. Kaitan Tingkat Pendidikan dengan 
Kepatuhan Minum Obat pada Pasien Tuberkulosis (TB) Paru di Puskesmas Bobotsari Kabupaten Purbalingga. Purwokerto: Program Studi Keperawatan SI STIKES Harapan Bangsa

Harnanik. 2014. Analisis Faktorfaktor yang Mempengaruhi Keberhasilan Pengobatan TB Paru di Puskesmas Purwodadi II Kabupaten Grobogan. Yogyakarta: Program Studi Ilmu Keperawatan Sekolah Tinggi Ilmu Kesehatan 'Aisyiyah

Kementerian Kesehatan RI. 2011. Pedoman Masional Pengendalian Tuberkulosis. Jakarta: Kementerian Kesehatan RI

Kementerian Kesehatan RI. 2014. Pedoman Nasional Pengendalian Tuberkulosis. Jakarta: Kementerian Kesehatan RI

Kementerian Kesehatan RI. 2015. Profil Kesehatan Indonesia 2014. (Online), (http://www.kemenkes.go.id), diakses pada tanggal 18 September 2016

Kholifah, Nur. 2009. Analisis Faktor yang Berhubungan dengan Kesembuhan Penderita TB Paru (Studi Kasus di BP4 Salatiga Tahun 2008). Semarang: Jurusal Ilmu Kesehatan Masyarakat Universitas Negeri Semarang

Ma'arif, Kholifatul. 2012. Pengaruh Peranan Pengawas Menelan Obat (PMO) terhadap Keberhasilan Pengobatan TB Paru di Wilayah Kerja Puskesmas Baki Sukaharjo. Surakarta: Fakultas Ilmu
Kesehatan Universitas Muhammadiyah Surakarta.

Muniroh. N, dkk. 2012. Faktor-faktor yang Berhubungan dengan Kesembuhan Penyakit Tuberkulosis (TBC) Paru di Wilayah Kerja Puskesmas Mangkang Semarang Barat. Jurnal Keperawatan Komunitas, 1 (1): 38-39

Nurmala H.S. 2002 Faktor-faktor yang Mempengaruhi Keberhasilan Program Penanggulangan Tuberkulosis (TB) Paru di Puskesmas Medan Helvetia. Sumatera Utara: Fakultas Kesehatan Masyarakat Universitas Sumatera Utara.

Nurlita, Dhina, dkk. 2015. Faktorfaktor yang Berhubungan dengan Status Kesembuhan Penderita Tuberkulosis Paru. Jurnal Kesehatan Masyarakat (e-journal), 3 (3): 141-151.

Nurna, Dea. 2015. Hubungan antara Karakteristik Penderita TB dengan Kepatuhan Memeriksakan Dahak selama Pengobatan. Jurnal Berkala Epidemiologi, 3 (2): 122-133.

Okanurak K, dkk. 2008. Factors contributing to treatment success among tuberculosis Patients: a Prospective Cohort Study in Bangkok. The International Journal of Tuberculosis and Lung Disease, 12 (10):1160-1165.

Somin, Pandapotan, dkk. 2014. Gambaran Peran Serta Petugas Kesehatan terhadap Kepatuhan Berobat Penderita TB Paru di Kelurahan Gambir Baru Kecamatan Kisaran Timur Tahun 2014. Medan: Fakultas Kesehatan 
Masyarakat Universitas Sumatera Utara.

Sugiyono. 2015. Metode Penelitian Kuantitatif, Kualitatif dan $R \& D$. Bandung: CV Alfabeta.

Tirtana, Bertin. 2011. Faktor-faktor yang Mempengaruhi Keberhasilan Pengobatan pada Pasien Tuberkulosis Paru dengan Resistensi Obat Tuberkulosis di Wilayah Jawa Tengah. Semarang: Fakultas
Kedokteran Universitas Dipenogoro

World Health Organization (WHO). 2015. Global Tuberculosis Report 2015. (Online), (www.who.int), diakses pada tanggal 4 September 2016

Yeti. Anita, dkk. 2015. Pengetahuan Pasien Tuberkulosis

Berimplikasi terhadap Kepatuhan Berobat. Jurnal Care, 3 (2): $\quad 37-42$ 